\title{
Pedagogic Competency of Islamic Religious Education Teachers in Developing Educational Learning Activities in SMP Negeri 20 Medan
}

\author{
Haidir1, Devi Umi Solehah $^{2}$, Khodijah Zuhro Annawawi Batubara ${ }^{3}$, Khairul Ameer ${ }^{4}$ \\ 1,2,3,4 Faculty of Tarbiyah and Teacher Training, Universitas Islam Negeri Sumatera Utara, Indonesia \\ deviumisolehah1111@gmail.com
}

\section{Abstract}

This study aims: (1) To determine how the instructional design of Islamic Religious Education teachers at SMP Negeri 20 Medan. (2) To find out how the implementation of Islamic Religious Education teacher teaching at SMP Negeri 20 Medan. (3) To find out what the teaching media for the Islamic Religious Education teacher at SMP Negeri 20 Medan. This research use desciptive qualitative approach. Data collection was carried out by observation, interviews, and documentation. Data analysis was carried out, namely examining all data, reducing data, presenting data, and concluding existing data.
Keywords

pedagogic competence, realizing

educational; leaming activities

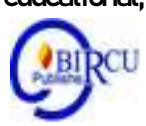

\section{Introduction}

The quality of an education system can be said to be good if it includes several signs including being able to encourage the creation of individual and group societies that are quality, creative and productive, and it can be said that the signs attached to a quality of education are good, namely with the creation of a learning activity process that goes well too. (PAI Student Research, 2020) Teachers or educators also have a very important relationship between roles as long as determining whether the quality and quantity in a teaching process has a focused role towards advancing the quality of education that is national in nature, which is comprehensive and nationally recognized. PAI Lecturer Research, 2020).

The National education system is based on Law Number 20 of 2003 on the content of the National Education System which is contained in Article 1: Education is felt as a form of business that is carried out consciously and planned in order to achieve a goal to create an atmosphere of learning (transfer or provision of knowledge ) as well as an active learning process so that students can develop processing power skills contained in him in order for strength processing power skillsreligious spirituality, self-control, personality, intelligence, noble character, and skills needed by him, society, nation and State.

Today, the status of teachers is a profession that has an important position, due to the preparation of skilled and reliable human resources (HR). Therefore, the teacher has a role that can be useful and expected, namely: 1) The teacher / educator is considered an agent of challeng or also called an agent of change. In the current era of very drastic transformation, the presence of a teacher has a role that is considered effective in driving and implementing change. 2) Teachers are considered coaches of tolerance and foster mutual understanding. At present, it is necessary to have an attitude of mutual understanding and tolerance for all creatures created by 
Allah called al-insan or human beings through the educational process. 3) Teachers are also considered professional educators.

Seeing the role of the teacher above, the role of the teacher is very important because it is responsible for preparing students to have high competitiveness in the future. Therefore, a teacher must have adequate competence, namely the existence of knowledge, skills, authority, skills, and also the power of the teacher in determining and deciding something.

In Government Regulation Number 74 of 2008 concerning Teachers Article 52: The workload of teachers includes the main activities: (a) planning lessons; (b) carry out learning; (c) assessing learning outcomes; (d) guideas well train students; as well (e) carry out additional tasks attached to the implementation of main activities in accordance with the teacher's workload.

According to the Regulation of the Minister of National Education Number 16 of 2007 concerning Academic Qualification Standards as well Teacher Competencies Point C Academic Qualification of SMP / MTs Teachers: Teachers at SMP / MTs, or other forms of equivalent, must have academic qualifications, minimum education diploma four (D-IV) or undergraduate (S1) study program in accordance with the subject taught / taught, as well obtained from an accredited study program.

In this case, the teacher is one of the important elements that must exist after the students. Teachers play a major role in education development, especially those held formally in schools. The teacher also plays a role in determining the success of students, especially in relation to the teaching and learning process. If a teacher does not have a professional attitude, the students being educated will find it difficult to grow and develop properly. This is because teachers are considered as one of the foundations for the state in terms of education. With the existence of teachers who are professional and also qualified, it will be able to produce quality children of the nation as well. The key that must be possessed by every teacher is considered a competency.

One of the competencies that a teacher must have is considered a pedagogic competence. Teacher pedagogical competence is the processing of a teacher's understanding skills of students, planning and implementing learning, evaluating learning outcomes, as well as developing learners to actualize their various potentials.

In addition, it is necessary to know that educational learning activities are very important in making the learning process effective in schools. An educational learning paradigm, namely learning that produces not only the basics of mastery of science and technology, but also fosters strong character and mastery of life skills (soft skills), so that they appear as human beings who love others (compassion) and respect high ethics in addition to trengginas in work. Only teachers are able in their daily duties to carry out this educational learning, and are also worthy of respect by the community and the government.

The processing of skills in organizing educational learning is not limited to information transmission (content transmission) as has so far been done in many Indonesian learning practices, but mainly in the form of providing a learning environment that facilitates the formation of complete skills processing in students.

As the results of the researchers' initial observations in the field show that teachers who teach at SMP Negeri 20 Medan in carrying out the teaching and learning process have made educational learning activities, this is a reference for teachers in implementing learning so that it can run effectively. But whether the educational learning activities made by the teacher can make each learning process effective, and also whether the educational learning activities carried out have been running effectively in accordance with the plans that have been made.

Researchers found that there were problems related to teacher competence in realizing educational learning activities. The problems are: the Learning Implementation Plan is made only in the form of a global reference and is also less detailed, the learning carried out by the 
teacher is not in accordance with the RPP made, does not choose the right learning method, and rarely uses learning media when delivering material. This shows that teachers do not fully have good competence in educational learning activities. This encourages the author to want to research more deeply and also because of the importance of a teacher's pedagogical competence in managing educational learning activities,

In this case, SMP Negeri 20 Medan as a formal education institution also has the responsibility to make its students become human beings with Muslim personalities, as is the goal of Islamic education. So the pedagogical competence of Islamic Religious Education (PAI) teachers is needed, so that the noble values of Islam taught at SMP Negeri 20 Medan are not only science (cognitive), but can be lived (affective), and also practiced (psychomotor) in daily life.

Therefore, the authors want to conduct closer research to find out how the competence of Islamic Religious Education (PAI) teachers which is focused on the pedagogical competence of Islamic Religious Education (PAI) teachers in realizing educational learning activities.

\section{Review of Literatures}

\subsection{Pedagogic Competence}

According to Barlow, teacher competence is quoted in Muhibbin Syah, namely the ability of a teacher to carry out duties responsibly and properly.(Shah, 2005, p. 229). Teachers also have legal firmness as stated in Government Regulation Number 74 of 2008 which discusses Teachers in Article 2 which contains: "Teachers have an obligation to academic qualifications, competence, teacher certificates, physical health.as well spiritual, as well also must have an effort to achieve the goals of national education ". (Government Regulation Number 74 of 2008, 2008, p.5)

According to Charles (1994) in the book E. Mulyasa, argues that: competency as rational performance which satisfactorily meets the objective for a desired condition (competence is a rational behavior to achieve the required objectives in accordance with the expected conditions. (E. Mulyasa, 2008, p. 25)

In the book written by the author Kunandar, he quotes Pietas well Ida Sahertian also argued that competence is a matter processing power skills (tallent) which is owned in doing something that is obtained through education as well training which is cognitive, affective, and performance. (Kusnandar, 2011, p. 52)

Competence is also considered as a knowledge or knowledge, skill or tallent, and is also seen as a foundation of values which can apply to a habit in the process of thinking and istiqomah. As well continuous in carrying out an action that creates a possibility that a person can have a competence, that is, obtaining knowledge, skills, as well the basic values of doing something.

This view also shares the same mind with what teachers do with their duties in education, that teachers must have the processing of skills or competencies in managing learning, as well as understanding students and designing learning so that it can be said that the teacher is competent. If the teacher does not have the competence in teaching, then

teaching is not in accordance with the processing of their skills, and if it continues, what happens in the learning process will not have meaning and results. Thus, learning carried out by teachers must have processing skills in their fields such as having pedagogical competence so that the teacher is able to produce maximum learning.

Competence considered a something processing power skillsto carry out a job (task) which is based on skillsas wellknowledge and supported by the work attitude demanded by the job. Competence also shows the characteristics of knowledgeas well skills possessed or needed 
by each individual to be able to perform a task as wellresponsibilities effectively and also raise the standards of professional quality, including among othersprocessing power skillsto transfer as well apply skills as well his knowledge. (Wibowo, 2007, p. 86)

Meanwhile, according to Syaiful Bahri Djamarah competence is a processing of skills that teachers absolutely have so that their duties as educators can be carried out well. Starting from this understanding, competence is something that cannot be separated from educational activities as well as teaching. In order to have a clear understanding of competence. (Syaiful Bahri Djamarah, 2002, p. 33)

\subsection{Learning Design}

Planning comes from the word "plan" which means making decisions to achieve goals. While learning comes from the word instruction which is widely used in the world of education in America. This word is heavily influenced by the flow of cognitive-holistic psychology, which places students as a source of activity. Gentry (1994) states that learning planning is a process that formulates and determines learning objectives, strategies, techniques, and media so that general learning objectives are achieved. (Wina Sanjaya, 2010, p. 88).

The following is the hadith of the Prophet Muhammad.

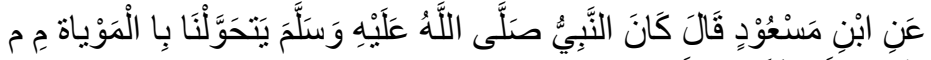

$$
\begin{aligned}
& \text { كَرَا هَةًَ السَّاَ مَةِة عَلَيْنَا. }
\end{aligned}
$$

Meaning: From Ibn Mas'ud, he recounts "The Prophet, always interspersed study days for us to avoid our boredom". (Narrated by al-Bukhari).

The hadith gives an understanding that the Prophet taught his friends not every day, but there was study time and there was also time to rest. This was done to avoid boredom with lessons. Thus he paid attention to the conditions of the friends (students) in teaching. They need time to rest. (Bukhari Umar, 2014, pp. 90-91)

Through this learning improvement it is hoped that it can improve the quality of learning carried out by lesson planning. (Hamzah B. Uno, 2007. p. 87). Furthermore, in designing learning, it is necessary to sort out the learning outcomes that can be measured immediately (direct results) and learning outcomes that are formed cumulatively which are derivatives of a number of learning events (accompanying results). Learning designers are often disappointed with the real results they achieve because there are a number of them because of the results that cannot be observed after learning ends, especially learning outcomes which are included in the attitude area. (Nyoman S. Degeng, 2000, p. 8)

\subsection{Implementation of Educational Learning}

The failure of the implementation of learning is mostly caused by the application of converged educational methods, anti-dialogue, the taming process, the inheritance of knowledge, and does not originate from the realities of society.

In the government regulation plan on teachers, that teachers must have the competence to carry out educational and dialogical learning. This means that the implementation of learning must depart from a dialogical process between fellow learning subjects, thus giving birth to critical thinking and communication. Without communication there can be no true education. Educative and dialogical learning is a response to the practice of anti-reality education, which according to Freire (2003), should be directed at the process of the problem. 


\subsection{Instructional Media}

\section{a. Learning Media}

The definition of learning media in a narrow sense means the components of materials and components of tools in the learning system. In a broad sense, media means the maximum use of all the system components and learning resources above to achieve certain learning objectives.

According to Hamidjojo, what is meant by media are all forms of communication roles (in this case including learning and teaching). Although there can be direct communication between learning, there is a role for learning media.

According Sukiman in Prasasti ( 2019) said that learning media is anything that can be used to channel messages from the sender to the recipient so that it stimulates the thoughts, feelings, attention, and interests and wishes of students in such a way that the learning process occurs in order to achieve the learning objectives effectively. Meanwhile, according to Wiarto (2016: 3), "learning media is a learning tool used to convey information to students that aims to make students know". From this statement, the understanding of instructional media is described based on the objectives

Learning media is divided into 6 (six) types, namely: (1) Text; (2) Audio; (3) Visual; (4) Motion; (5) Real objects and models; and (6) People [1]. The most commonly used learning media is text-shaped media. This type of text media is used to convey learning material in the form of books, posters, whiteboards, computer screens and others. Other types of media that are often used as learning media are audio, including anything that can be heard, for example, human voice conversations, music sounds, mechanical engine sounds, and others. Visual type learning media are such as diagrams in a poster, images posted on walls (eg wall charts), pictures on a blackboard using chalk or markers, graphics in a learning book, photographs of objects, and others. Motion is a learning media in the form of motion such as videotape, film, and animation. Real objects or models are learning media in the form of three dimensions that can be touched and held by students. An example of a model-shaped learning media commonly used in vocational learning is "trainer"[4]. The last type of media is humans, namely teachers, students, or experts in their fields. Students can learn through teachers, fellow students, or to an expert in their fields. (Pratama et al, 2021)

So the understanding of learning media can briefly be stated as something (it can be a tool, material, or situation) that is used as an intermediary for communication in learning activities. So there are three concepts that underlie the limitations of learning media over the learning system and concepts.

\section{b. Types of Learning with Learning Media}

Today there are still many teachers who are reluctant to use the media to become very popular / famous by the name of the cone of experience from Edgar Dale, which consists of 11 levels, including: direct experience, observation, participation, demonstration, tourism, TV , film, radio, visuals, visual symbols and verbal symbols (words). At that time the teachers were very attracted to this cone of experience, because it could be used as a guide in choosing what tools were suitable for the teacher to use.

At the end of the 1950s, communication theory began to influence the use of audio-visual aids, so that the function of the media as teaching aids began to shift to channel learning messages / information. The 1960s BF theory of behavior. Skinner, began to influence the use of media that can change student behavior.

Since 1965, the use of a systems approach has begun to enter the realm of education and learning activities. This systems approach encourages the use of media as an integral part of the learning program. Even James W. Brown (1977), a figure in the fields of technology, media 
and learning methods, sees media as central elements, saying: "Media are considered as centralelements in the approach to the systematic instruction". Programs that include learning media are implemented systematically based on the needs and characteristics of students and are directed to changes in behavior according to the competencies that must be mastered.

Mukhtar argues that media literally means an intermediary, an introduction or a vehicle for channeling messages and delivering learning information, this shows that the media is a container of messages conveyed by resource persons channeled by the teacher, which is forwarded to the target of acceptance, namely students who are learning. (Mukhtar, 2003, p. 103).

\section{Research Methods}

The approach used in this study using a phenomenological approach. Phenomenology is the science of describing what a person receives, feels and knows in his direct awareness and experience, what arises from that consciousness which is called a phenomenon. Here the researcher conducts research by going directly to the field, describing and constructing the existing reality and making an approach to information sources, so that it is hoped that the data obtained will be maximized.

In this study, the primary data source in the form of words was obtained through interviews with informants who had been determined covering various things related to the pedagogical competence of Islamic Religious Education teachers in realizing educational learning activities at SMP Negeri 20 Medan. While the secondary data sources in this study were school data, namely vision and mission, organizational structure data, data on the number of teaching staff and education personnel both civil servants and honorariums, data on the number of education personnel and education personnel, data on the number, data on the number of education personnel according to the subjects taught, data on the state of facilities and infrastructure, and data on the number of students in SMP Negeri 20 Medan.

Data collection methods used to collect data in this study using observation, interview and documentation techniques. Activities in qualitative data analysis are carried out interactively and continue to completion, so that the data is saturated, namely as follows: data reduction, display data, and conclusion drawing / verifacation. The technique of checking the validity of the data in this study is triangulation. Triangulation is the best way to eliminate differences in reality construction that exist in the context of a study when gathering data about events and relationships from multiple views. Whereas for Data validity test in qualitative research, namely credibility test, transferability, dependability, and confirmability.

\section{Result and Discussion}

\subsection{General Findings}

This research was conducted in SMP Negeri 20 Medan which is located at Jalan Kapten Rahmad Buddin, Medan Marelan District, Medan City, North Sumatra Province and is well accredited (B). Currently the school is led by Bpk Drs. Halpan Siregar, MM as the principal. SMP Negeri 20 Medan is continuously racing in improving service quality and implementation in achieving its goals, vision and mission. So that until now it has become one of the favorite schools in the Medan Marelan sub-district and attracts the interest of the wider community. At SMP Negeri 20 Medan, students are directed and nurtured to excel with faith and piety and love the environment. The teacher at SMP Negeri 20 Medan in teaching the educators subject is in accordance with his last education. In addition to the subjects taught, educators also have employment status (PNS / Honorer). The students consist of 30 class groups, namely class VII 
consisting of 10 student rooms totaling 342 students, class VIII consisting of 10 student rooms totaling 351 students, and class IX consisting of 10 student rooms totaling 338 students.

\subsection{Special Findings}

The specific findings in this study are directed at the effort to reveal the findings of research in the field which are guided by the research problem of the presence of Islamic Religious Education teachers whose lesson plans are made only in the form of global references and are less detailed, the learning carried out is not in accordance with the lesson plans made, does not choose the right learning method before delivering learning material to students, and rarely uses learning media. The following results have been obtained from the field in the form of interviews conducted by researchers.

\section{a. Islamic Religious Education Learning Design}

The results of the data analysis of the researcher with the informant as the teacher of Islamic Religious Education, regarding the learning design that the informant before carrying out the learning first made an Implementation Plan (RPP), the making of the Learning Implementation Plan (RPP) was not made by the informant, but downloaded from the internet site because informants cannot make their own Learning Implementation Plan which has been adjusted by the National MGMP, especially the subject of Islamic Religious Education and is in accordance with the provisions of the government's RPP. The components of the Learning Implementation Plan (RPP) that the informants download are subject identity, competency standards, basic competencies, competency achievement indicators, learning objectives, teaching materials, time allocation, learning methods, learning activities, assessment of learning outcomes, and learning resources, while the Learning Implementation Plan (RPP) according to the government is subject identity, competency standards, basic competencies, competency achievement indicators, learning objectives, teaching materials, time allocation, learning methods, learning activities, assessment of learning outcomes, and learning resources. This is in line with the researcher interview with the informant as the Islamic Religious Education teacher, regarding the learning design he stated: and learning resources. This is in line with the researcher interview with the informant as the Islamic Religious Education teacher, regarding the learning design he stated: and learning resources. This is in line with the researcher interview with the informant as the Islamic Religious Education teacher, regarding the learning design he stated:

As a teacher, of course, you have to make a lesson plan (RPP) before implementing the lesson, and the lesson plan will be checked by the supervisor and given an assessment. Learning planning is a very important step before implementing the teaching and learning activities. Teaching and learning activities (KBM) require careful planning to run effectively and facilitate the learning process. (inf. PP)

\section{b. Implementation of Educational Learning}

Implementation of learning is a process that provides an explanation that the learning process already has the necessary human resources and infrastructure, so that it can form competencies and achieve the desired goals. The stages of implementing educational learning are:

1) Preliminary activities include the readiness of students in receiving subject matter, praying, reading the verses of the Koran, giving questions about the material to be discussed. The results of the data analysis of the researcher with the informant as the Islamic Religious Education teacher were in line with the interview between the researcher and the informant, regarding the preliminary activities, he stated: 
The things I do when I want to start learning for the first time I pay attention to the students whether they are ready to follow the learning well, if the students are ready to follow the learning well then I ask the class leader or other students to bring learning prayers so that other students following, when I finished praying I asked the students to read the verses of the Koran, after the students finished reading the verses of the Koran I gave questions about the learning material that had been discussed and linked it to the next material. (inf. KP)

2) The core activities include the implementation of the pre-test and the use of learning methods. The results of the data analysis of the researcher with the informant as the Islamic Religious Education teacher were in line with the interviews conducted between the researcher and the informant regarding his core activities, he stated:

The pre-test is done to find out the basic knowledge of students about the material that we will convey, and from this pre-test it can also be seen that students who already know better than their friends. This can create a learning atmosphere where students will feel closer when their friends explain in the language and intonation of their daily interactions, even if there is something wrong it can be straightened out by the teacher later, from the pre-test many basic materials that can be we flash back when the learning has taken place, this effect can help plug a stronger memory in students. However, it is still difficult for the pre test to be carried out at every meeting due to unsupportive factors, such as the absence of students who dare to express their knowledge regarding the material to be taught. (inf. PPT)

The teaching methods I use most often are the lecture method, the discussion method, and the question and answer method, as well as the memorization method. When I am asked about the method, I think that the method refers to a unity in which there is material, media, and evaluation. We all already know that every subject must require a method as a way to convey the material and in Islamic Religious Education subjects, most of the material is inseparable from the verses of the Koran and Hadith, here I usually use the method of memorizing students. However, before I memorize the students, I first invite them to discuss material related to the verses of the Koran or Hadith that they will memorize. Therefore, they will more or less understand the meaning of memorized verses from the Koran or Hadith. (inf. PMP)

3) Closing activities. The results of the analysis of the researcher data with the informant as the Islamic Religious Education teacher were in line with the interview between the researcher and the informant, regarding the closing activity, he stated:

At closing the first lesson, I and the students concluded the subject matter discussed, then I gave feedback to my students, after giving feedback I gave group assignments to students to discuss the subject matter at the next meeting. After giving group assignments to students, I asked the class leader or other students to bring a closing prayer for learning so that other students could follow, therefore the learning activities had been completed at the meeting. (inf. KP)

\section{c. Islamic Religious Education Learning Media}

The results of the data analysis of the researcher with the informant as the teacher of Islamic Religious Education, regarding the use of learning media and mastery of the subject matter showed that the informant did not often use learning media because the facilities provided by the school were less supportive. This is in line with the researcher interview with the informant as the teacher of Islamic Religious Education, regarding the use of learning media, he stated: 
It's not that often, but within a month I made 2 instructional media, sometimes through infocus. There are several obstacles when I use learning media when the practice does not complete what we ask for, then it takes the form of a kind of discussion and a rule is made that for next week there must be preparations for implementing the learning media that was designed in the previous week, this is because of the facilities provided by the school. less supportive. (inf. MPPAI)

Based on the results of research on the pedagogical competence of Islamic Religious Education teachers in realizing educational learning activities, it was found that Islamic Religious Education teachers at SMP Negeri 20 Medan had shown the competencies they had. Teachers of Islamic Religious Education at SMP Negeri 20 Medan can prepare pre-teaching planning, carry out educational learning which includes preliminary activities, conduct pretests, use methods, cover activities, use media and factors that affect educational learning activities. Learning Designwhat has been made by the Islamic Religious Education teacher has gone as planned, although not completely, because there are several factors that are less supportive.

Implementation of Educational Learninginclude: Preliminary activities before carrying out learning, the Islamic Religious Education teacher who was successfully interviewed by the researcher, that before carrying out the learning activities the Islamic Religious Education teacher opened a lesson in which one of the Islamic Religious Education teachers when opening the lesson told his students to read the prayer prayer, after The students have finished reading the prayer prayer, one of the Islamic Religious Education teachers immediately asked their students about the learning material that had been discussed and linked it to the next material. Furthermore, the core activity is a process of learning activities which includes: Implementation of pre-tests before learning, The Islamic Religious Education teacher who was successfully interviewed by the researcher said that the pre-test made it very easy for Islamic Religious Education teachers to carry out learning activities, from the pre-test the teacher would know the initial knowledge possessed by students related to the material to be discussed. By knowing how students understand the material to be taught, the teacher will find it easier to know what the learning process will be like. In using the method as a technique in teaching, they have used appropriate learning methods, and carried out learning according to what has been written in the lesson plans they made, even in the learning process of Islamic Religious Education teachers who combine various methods on a learning topic, based on the results of observations of researchers in the field, Islamic Religious Education teachers often use the lecture method when delivering learning material, there are also using learning methods that are in accordance with the subject matter being taught. In the learning process the teacher must be able to master and use a variety of learning methods in order to make it easier to convey the subject matter to students, but this is difficult for the teacher to do. Some teachers are lazy to use other methods, they more often and prefer to use the lecture method on the grounds that the lecture method is easier to do and does not require much preparation.

Instructional Mediahas an important meaning, the media is useful as a tool for teachers to convey messages and information to students, therefore the media must be communicative. Through the use of media it is expected to open horizons and insight into students' thinking so that they can understand the whole concept in learning. With the existence of media students are expected to be able to receive and absorb the messages well, the use of learning media in schools is very much determined by the ability of the teacher to manage the use of the learning media. In using the learning media for the Islamic Religious Education teacher at SMP Negeri 20 Medan, it is quite good, because at SMP Negeri 20 Medan, media or learning resources such as textbooks are given by schools to students and there are several props. However, based on the results of the interviews obtained by researchers, the teachers explained that they rarely 
used varied learning media when delivering subject matter. This is due to the incomplete facilities provided by the school, besides that there are several media that the teacher wants to use to deliver learning but the classroom conditions are less supportive and not conducive. In accordance with the observations of researchers in the field in terms of mastering the subject matter of Islamic Religious Education teachers at SMP Negeri 20 Medan, they are able to master the material in the subject of Islamic Religious Education being taught. This can be seen clearly when the researcher observes the teacher while doing learning in the classroom, that each material presented can be explained quite well.

\section{Conclusion}

1. The learning design that has been made by the Islamic Religious Education teacher at SMP Negeri 20 has been running as designed, although not completely appropriate, due to several factors that are less supportive.

2. The implementation of Islamic Religious Education teacher learning at SMP Negeri 20 Medan, which includes: Preliminary activities before carrying out learning, Islamic religious education teachers who were successfully interviewed by researchers, that before carrying out learning activities, the Islamic Religious Education teacher opened learning, instructing students to read prayer learning, after the students had finished reading the prayer prayer, one of the Islamic Religious Education teachers immediately asked the students about the learning material that had been discussed and linked it to the next material. Furthermore, the core activity is a process of learning activities which includes: the implementation of the pre-test for Islamic Religious Education teachers at SMP Negeri 20 Medan before starting learning, The pre test was conducted in the form of a verbal question and answer. However, most teachers rarely carry out pre-tests in the form of written tests. In the use of learning methods, the methods used when implementing learning are also quite varied. The teacher is able to adjust the method with the material being taught, then when delivering the subject matter the teacher does not only use a method but there are many variations of the method used, although there are still a small number of Islamic Religious Education teachers who more often use the lecture method.

3. Learning media is used as a learning resource and has been adapted to the learning needs of students, although not all subject matter can use learning media. There are some subject matter whose media cannot be facilitated by schools and teachers also cannot make efforts to provide such media. Thus the teacher is able to adjust the media used with the teaching methods and materials. However, there are also Islamic Religious Education teachers who rarely use media in the learning process. Learning media that are often used when learning is taking place are media in focus, media images (posters), and audio-visual media. 


\section{References}

Azhar Arsyad. (2010). Media Pembelajaran, Jakarta: Raja Grafindo Persada.

Arief S. Sardiman. (2014). Media Pendidikan Pengertian, Pengembangan, dan Pemanfaatannya, Jakarta: PT RajaGrafindo Persada.

Aqib. (2013). Model-Model, Media, dan strategi Pembelajaran Kontekstual (INOVATIF), Bandung: Yarma Widia.

Ahmad Tafsir. (2014). Pengembangan Peserta Didik,

Bukhari Umar. (2014). Hadist Tarbawi: Pendidikan dalam Perspektif Hadist, Jakarta: Amzah.

Dosen Pengampu dari Mahasiswa Program Studi Magister PAI Reguler Fakultas Ilmu

Tarbiyah dan Keguruan, Universitas Islam Negeri Sumatera Utara. Tahun 2020.

Heri Gunawan. (2012). Kurikulum Dan Pembelajaran Pendidikan Agama Islam, Bandung: Alfabeta.

Hamdani. (2011).Strategi Belajar Mengajar, Bandung: CV Pustaka Setia.

Harjanto. (2000). Perencanaan Pengajaran, Jakarta: PT. Rieneka Cipta.

James W. Brown. (1977). Tokoh Bintang Technologi.

Kusnandar. (2011). Pendidikan Pelatihan yang Sifatnya Kognitif, Afektif, Serta Performa.

Iif Khoiru Ahmadi dan Sofan Amri. (2010). Strategi Pembelajaran Sekolah Berstandar Internasional dan Nasional, Jakarta: Prestasi Pustakaraya.

Mukhtar. (2003). Desain Pembelajaran Pendidikan Agama Islam, Jakarta: Misaka Galiza.

Munadi Yudhi. (2013). Media Pembelajaran, Jakarta: GP Press Group.

Musfiqon. (2012). Pengembangan Media dan Sumber Pembelajaran, Jakarta: PT. Prestasi Pustakarya.

Mahasiswa Program Studi Magister PAI Reguler Fakultas Ilmu Tarbiyah dan Keguruan, Universitas Islam Negeri Sumatera Utara. Tahun 2020.

Mulyasa. (2008). Tujuan Kompetensi Guru dan Peserta Didik.

Nasir A. Baki. (2014). Metode Pembelajaran Agama Islam.

Nana dan Rivai. (2009). Media Pengajaran, Bandung: Sinar Baru Algensindo.

Nuryani. (2015). Strategi Belajar Mengajar Biologi, Surabaya: UM Press.

Peraturan Menteri Pendidikan Nasional Republik Indonesia No. 41 Tahun 2007 tentang

Standar Proses Untuk Satuan Pendidikan Dasar dan Menengah Badan Standar Pendidikan. Peraturan Pemerintah No. 74 Tahun 2008

Prasati, T. et al. (2019). The Effectiveness of Learning Media Folklore Text of North Sumatera Based on Blended Learning by $10^{\text {th }}$ Grade Students of Vocational High SchoolHarapan Mekar-1 Medan. Budapest International Research and Critics in Linguistics and Education (BirLE) Journal. P. 480-490.

Pratama, Y. et al. (2021). Develop an Android-Based Learning Media Integrated with a Scientific Approach to the Colligative Solution's Nature. Budapest International Research and Critics in Linguistics and Education (BirLE) Journal. P. 322-329

Rayandra Asyhar. (2011). Kreatif Mengembangkan Media Pembelajaran, Jakarta: Gaung Persada.

Uyoh Saduloh. (2007). Pedagogik Seluk Beluk Pendidikan. 2011.Undang-undang Dasar, No.14. 2005.Wibowo, Keterampilan.

Yaumi Muhammad. (2012). Buku Daras Desain Pembelajaran Efektif, Makassar: Alauddin Universitas Press.

Zaenuddin Ahmad Azzubaidi. (1986). Terjemah Hadis Shahih Bukhari, Semarang: CV. Toha Putra. Zakiah Daradjat, et al. (1996). Metodologi Pengajaran Agama Islam, Jakarta Bumi Aksara.

Wina Sanjay. (2019). Media Komunikasi Pembelajaran, Jakarta: Kencana Prenada Media Group.

Zainul Abidin. (2016). Jurnal Penerapan Pemilihan Media Pembelajaran, Volume 1 Nomor 1. 